\title{
The integration of the terrestrial and airborne laser scanning technologies in the semi-automated process of retrieving selected trees and forest stand parameters
}

\author{
Integração das tecnologias terrestre e aerotransportada de scanner laser \\ no processo semi-automático de recuperação de árvores selecionadas e \\ de parâmetros de povoamentos florestais
}

Piotr Wezyk'

\begin{abstract}
The traditional forest inventory based usually on thousands of the circle plots (radius $=12.62 \mathrm{~m}$; area $500 \mathrm{sq} \mathrm{m}$ ) set in regular network. On every inventory plot, the basic tree and forest stand parameters have to be collected using calliper and hypsometer or even human eye (i.e. crown closure) as well. The modern multifunctional forestry models requires more and more: dens and accurate data to deliver as fast as possible the precise information on the amount of wood stock or other selected forest stand and tree parameters. One of the promising remote sensing technologies is LiDAR collecting the $3 \mathrm{D}$ point cloud data. The TLS technology is very precise and fast but is limited to relatively small areas like forest inventory plot. The ALS is more focused on wide-area data collection. Both technologies are complementary, therefore it is a need for the fusion of those two sources of information to enhance the accuracy of tree parameters and enlarge the results for the wide forest areas with statistical models. Paper presents a method of the TLS and ALS point cloud registration and transformation to one coordinate system. The goal of the data fusion was the semi-automatic extraction of the trees selected parameter (height, DBH, basal area, crown closure, base of crown, 2D and 3D tree crown surface) of the TR2 transect in Niepolomice Forest (Krakow, Poland). The results showed that the big potential of the enhancement of height and crown closure or base of the crown exists.
\end{abstract}

Key words: TLS; ALS; LiDAR point clouds integration; forest taxation parameters.

\section{Resumo}

O inventário florestal tradicional baseia-se normalmente em milhares de parcelas circulares (raio $=12,62 \mathrm{~m}$, área $500 \mathrm{~m}^{2}$ ) dispostas em uma malha regular. Em cada parcela do inventário, os parâmetros básicos da árvore e do povoamento devem ser

I Laboratory of Geomatics, Faculty of Forestry, Agricultural University in Krakow, al. 29 Listopda 46, 3 I-425 Krakow, Poland; E-mail: rIWEZYK@cyf-kr.edu.pl

Recebido para publicação em 06/07/2012 e aceito em I I/09/2012

\begin{tabular}{llllll}
\hline Ambiência Guarapuava (PR) v.8 Ed. Especial & p. 533 - 548 Outubro 20I2 & ISSN I808-025I
\end{tabular} DOI: $10.5777 /$ ambiencia.2012.04.08 
coletados usando suta e hipsômetro ou até mesmo o olho humano (densidade de copa). Os modernos modelos florestais multifuncionais requerem cada vez mais: dados densos e acurados para gerar o mais rápido possível a informação precisa da quantidade de estoque de madeira ou outro parâmetro selecionado do povoamento e da árvore. Uma das tecnologias promissoras de sensoriamento remoto é o LiDAR coletando os dados da nuvem de pontos 3D. A tecnologia TLS é muito precisa e rápida mas limitada a áreas relativamente pequenas como as parcelas de inventários florestais. A ALS é mais focada na coleta de dados em grandes áreas. Ambas as tecnologias são complementares portanto, é necessário para a fusão das duas fontes de informação aumentar a acurácia dos parâmetros de árvore e ampliar os resultados para grandes áreas florestais com modelos estatísticos. $\mathrm{O}$ artigo apresenta um método de registro e transformação do TLS e nuvem de pontos do ALS para um sistema de coordenadas. O objetivo da fusão dos dados foi a extração semi automática de parâmetros selecionados de árvores (altura, DAP, área basal, densidade de copa, base da copa, área 2D e 3D da copa da árvore) do transecto TR2 da Floresta Niepolomice (Krakow, Polônia). Os resultados mostraram que o grande potencial do aprimoramento da altura e do densidade de copa ou da base da copa existe.

Palavras-chave: TLS; ALS; integração da nuvem de pontos LiDAR; parâmetros.

\section{Introduction}

Sustainable forest economy demands very precise data on vertical and horizontal structure of the tree stand and biomass of forest resources. The measurements of trees carried out with traditional methods on inventory circle plots, usually refer to the tree diameter at breast height $(\mathrm{DBH})$, height (h) and the number of trees (e.g. density parameter) of tree species per unit of the area. The forest inventory campaign are very time and cost consuming, thus, there is a need to use the methods based on remote sensing technologies, which would speed up the measurements and significantly reduce the costs (KOK; WEZYK, 2008; WEIDENBACH et al., 2008). One of such dynamically developing technologies is LiDAR (Light Detection And Ranging), both in airborne (ALS) as well as terrestrial laser scanning (TLS; MLS - Mobile Laser Scanning). The LiDAR technology allows quick obtaining information in the form of the $3 \mathrm{D}$ point clouds $(\mathrm{XYZ})$ representing the vertical and horizontal structure of tree stands. TLS and ALS are obtained from the opposite localizations, which results in the case of each of them in certain failures referring to precise determine of the taxation parameter, or even completely excludes this. These methods are not contradictory, but complementary, like: LiDAR and Photogrammetry. The key to the success of using the advantages of each of LiDAR technologies is the data fusion by correct registration often achieved by manual geometric transformation of TLS scanner coordinate system into the ALS coordinate system (DONEUS et al., 2010). The development of technology causes that more and more data (e.g. LiDAR, multi- and hyperspectral images) collected by the devices mount on different platforms (terrestrial, mobile, airborne, UAV) can be integrated in CAD/GIS systems, using the position and time pattern (GPS), IMU/INS, detection of 
the edges of buildings (HANSEN et al.,2008) or surveying transformations using the direct measurement of the objects (plains/surfaces) (PERRY; CHILDS, 2009) or scanner stands (DONEUS et al., 2010) as well.

The forestry application of TLS in obtaining selected taxation parameters of trees in a manual or automatic way have been known for only a few years (BIENERT et al., 2007; HOPKINSON et al., 2004; WEZYK et al.,2008,2010c; WEZYK; TOMPALSKI, 2010). The results obtained by individual authors depended mainly on a specific type of the scanner and its integration with other devices like ALS (CHASMER et al., 2006, as well as on the parameters of the tree stand itself (DANSON et al., 2006). TLS technology allows getting such taxation features and parameters of trees such as: the location of the tree, $\mathrm{DBH}$, the tree $(\mathrm{g})$ and stand $(G)$ basal area, tree height, length and width of the tree crown, length of the branchless part of the trunk, canopy density, tree stem density, taper of the trunk and its curvature, the leaf area index (LAI), the angle of branches, trunk thickness, vertical profile of the variability of tree stands biomass, trunk quality (texture of wood fibres, damages), detection of understory and natural regeneration, etc. (ASCHOFF; SPIECKER, 2004; HOPKINSON et al., 2004; DANSON et al., 2006; BIENERT et al., 2007; MAAS et al., 2008). While the application of TLS technology has a limited range (usually forest inventory circle plots), the use of ALS refers to wide-area projects. In tree stands of high density ALS point cloud can often provide more precise information than TLS data on the height of the tree stand or provide basis for the canopy modelling (ANDERSEN et al., 2006; CHASMER et al., 2006; WEZYK et al., 2008, 2010b).
Some limitations of ALS refer to the space of the tree stand under the canopy, i.e. lower parts of the tree crown, trunk and ground as well. While the percentage of ALS impulses reaching the forest ground usually allows a precise Digital Terrain Model (DTM), both obtaining information on trunk location, $\mathrm{DBH}$ or the basis of the tree crown is very limited, although possible by the prediction of the relationship of $\mathrm{DBH}$ with the height of the tree and the density (size of crown) of tree stand (WEZYK et al., 2010a). Other taxation parameters of trees and tree stands as well as the spatial features can be successfully defined by the analysis of the ALS point cloud. The following features can be included: the horizontal range of the tree stand, height (e.g. $\max Z$, 95 percentile), density or penetration of canopy, the number and location of trees, biomass, the base of the crown, $2 \mathrm{D}$ and $3 \mathrm{D}$ surface of the crown and others such as the crown volume (HYYPPÄ et al., 2004; HOLLAUS et al., 2007; WEZYK, 2008; WEZYK; SIECZKA, 2010; WEZYK et al., 2010a, 2010b; McGAUGHEY, 2012). Mutual supplementation of the information originating from two sources of data, i.e.: very precise local TLS and wide-area ALS now become almost the requirement in constructing correct statistical models describing e.g. the development of tree stands and their characteristic.

The purpose of the paper was to demonstrate the added value of the integration of the point clouds from complementary systems: terrestrial laser scanning with airborne laser scanning - to enhance the supplementation and information in terms of the semi-automatic extraction of selected taxation parameters of trees and tree stands. 


\section{Test Area}

The presented study was performed on the research transect $(100 \mathrm{~m} \mathrm{x} 125 \mathrm{~m})$ on the so called "TR2", established in the mixed oak-pine stands (Pino-Quercetum community) of the Niepolomice Forest (wooded area: 10,507 ha; N: 50'02'26.28'; E: 20²3'06.18"; South Poland, figure1) in the framework of the FOREMMS project (5FP UE) in the 2001 year (SOCHA; WEZYK, 2007). The main forest tree species here are: Scots pine (Pinus sylvestris L.) occupying $64.5 \%$ of total wooded area, common oak (Quercus robur L.) and sessile oak (Quercus sessilis L.) - together 20.4\% and European black alder (Alnus glutinosa Gaertn.) with an area of $10.9 \%$. The mean age of the stands in Niepolomice Forest stands is 65 years and the biomass reaches approx. $282 \mathrm{~m}^{3} /$ ha with increment of $5.02 \mathrm{~m}^{3} /$ ha/year.
The radius of TR2_TLS was 4 times bigger (radius: $25 \mathrm{~m}$; area: $1963.5 \mathrm{~m}^{2}$ ) than common forest inventory plot used in Polish State Forest (radius: $12.62 \mathrm{~m}$; area: $500 \mathrm{~m}^{2}$ ). On the TR2_TLS plot, the 44 trees with DBH $>7 \mathrm{~cm}$ were found, i.e.: 24 Scots pines, 19 common oaks ( 5 trees in the storey II of the tree stand) and 1 Silver birch. All the trees (ofDBH>7 cm) were numbered on the whole TR2 area in 2001 and measured on the circle plot TR2_TLS with traditional methods. The $\mathrm{DBH}$ was defined in 5 directions with the calliper (accuracy 0.01 $\mathrm{m})$ in 2006. The first measurement marked DBH_1 means the transverse measurement towards the direction of falling laser beam on the tree trunk from the scanner stand S_1. The subsequent referred to: $\mathrm{DBH}$-2 - according to the direction of the laser and subsequent DBH_3 $\div 5$ transversely to the remaining stands of scanner $\left(\mathrm{S} \_2 \div 5\right)$ and the perimeter of the tree was measured with the tape (0.01

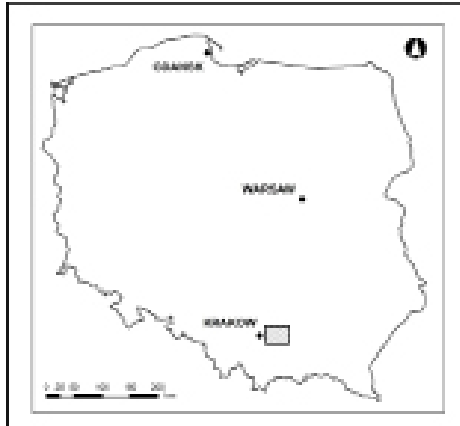

a)

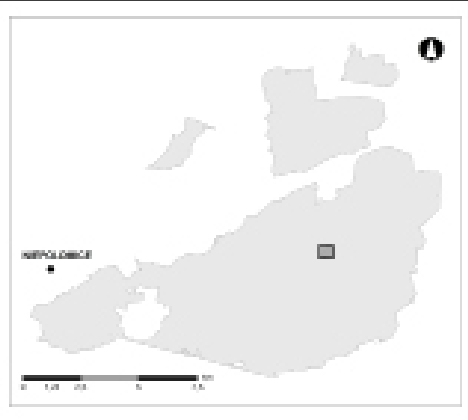

b)

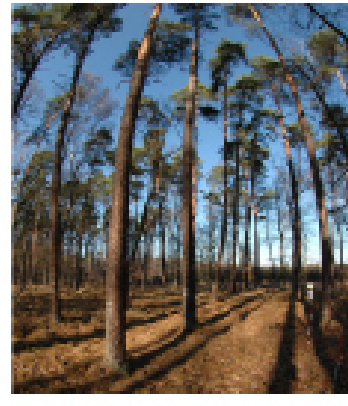

c)

Figure I. Localization of the test site in Niepolomice Forest near from Krakow, South Poland (a), the research transect TR2 in forest compartment II3d (b) and the view of theTR2_TLS inventory plot (c).

\section{Material and Methods}

\section{Reference Measurements}

In November 2006 the localization of the experimental forest inventory plot, called TR2_TLS was chosen and stabilized in the central part of the research transect TR2. $\mathrm{cm})$. The height of the tree was defined by the hypsometers of Vertex II (Haglöf). All the locations of tree trunks were measured with the polar method from stand S_1.

On the "King's road" lying near the transect TR2, in the places of significantly uncovered horizon, two survey points were permanently stabilized. The first of them 
- GPS_10 made the beginning and end of the traverse. Point GPS_11 making the reference of the traverse located on the cross road (distance $192.36 \mathrm{~m}$; azimuth 245.43). To make GPS static observation, the Leica receivers: GX1230GG (GPS_10) and GS15 VIVA (GPS_11) were used (GEOSAT Krakow). Reference measurements of the centre of theTR2_TLS circle plot (S_1) were made with the method of the traverse (Total Station: Topcon GTS 212). The observations of the distances and directions in subsequent points: GPS_10, 03, 02, 01, S_1, 01, 02, 03 and GPS_10 (Figure 2) were done.

\section{Airborne Laser Scanning}

ALS data were obtained with scanner REIALS data were obtained with scanner REIGL LMS-Q560 in September 2006 from the Eurocopter (Milan Flug; Germany), at the height $450 \mathrm{~m}$ over the ground. Two strips of the flight (width of about $500 \mathrm{~m}$, density approx. $3 \mathrm{pts} / \mathrm{m}^{2} ; \mathrm{FE} /$ LE) covered the study area TR2, so that, the density of the ALS cloud points in total was ca. $6 \mathrm{pts} / \mathrm{m}^{2}$ (Figure 3). Due to the lack of buildings typically used as georeferencing KAGER, 2004), in the direct proximity of the flight, height and situation adjustment was carried out based on IMU/GPS and measured GCP's (dGPS/tachymetry) and plains of adjustment located on the forest roads fragments with open horizon. ALS point cloud (Figure 3) was written in the projection UTM 34N and the Polish height reference system (Kronsztad 86; MSL).

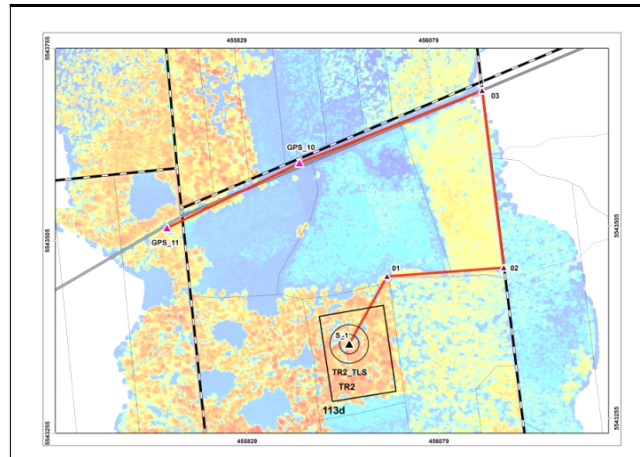

a)

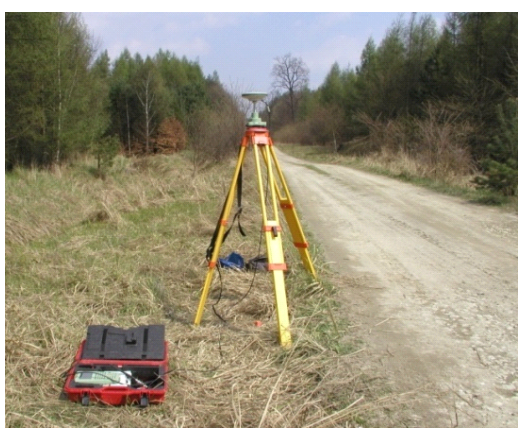

b)

Figure 2. The traverse from GPS_I0 to S_I done with Total Station Topcon GTS 212 (a) and the dGPS static RTK survey of GPS_10 using the GXI230GG Leica GPS receiver (b)

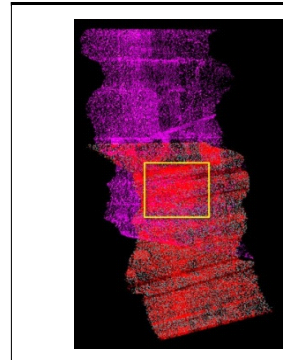

a)

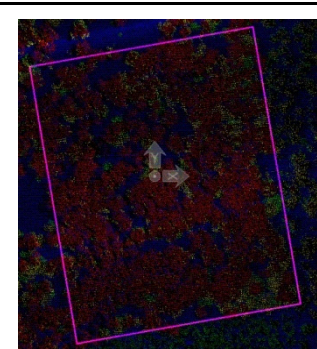

b)

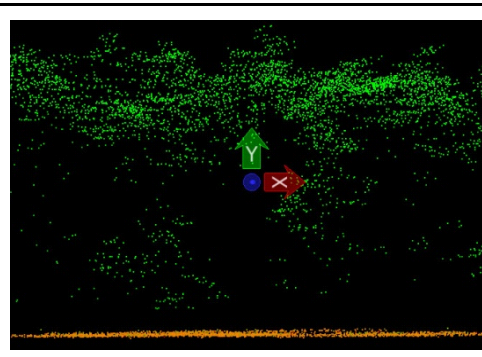

c)

Figure 3. The two ALS strips (magenta ID=6; red ID=7) (a) and enlarged area of TR2 transect (b; colors by absolute elevation) and profile of classified data set (c) 


\section{TLS Hardware}

In November 2006 the scanner FARO LS880 HE80, based on phase shift technology, was used. FARO operates within the range $360^{\circ}(\mathrm{H})$ and $320^{\circ}(\mathrm{V})$. The option $1 / 4$ of full resolution was applied (size of single scan 160 MB; scanning time of about 7 minutes). To manage the scans and combine them, based on 5 reference spheres (radius: $7.25 \mathrm{~cm}$ ), the software FARO Scene ver. 4.0 was applied.

\section{TLS Forest Inventory Method}

Multi-stand method of scanning (WEZYK et al., 2007) assumes 1 central position S_1 and 3 additional ones (S_2, S_3 and S_4) located out of the radius of the standard circle plot ( $\mathrm{r}=12.62 \mathrm{~m}$; area: $\left.500 \mathrm{~m}^{2}\right)$ but not further than $16 \div 17 \mathrm{~m}$ from spheres, was applied. Such a location of TLS scanners regarding the visibility of minimum 3 spheres from each position, allows the imaging tree trunks as 3D, almost from every side (Figure 4).

\section{Relative Orientation ofTLS Point Cloud}

The cloud of points from 4 stands of FARO scanner were connected by identifying and numbering the spheres in FARO Scene software. The matched data were exported to ASCII (XYZI) file format in the local coordinates system of the scanner LSRS (Local Scanner Reference System) (0,0,0). In the next steep, the imported point cloud TLS was written into binary format and LAS 1.2 (TerraScan, Terrasolid).

\section{Registration of TLS Point Cloud}

The key step of the integration of the ALS and TLS point clouds is their registration to common coordinates system. ALS point cloud is transferred by the supplier

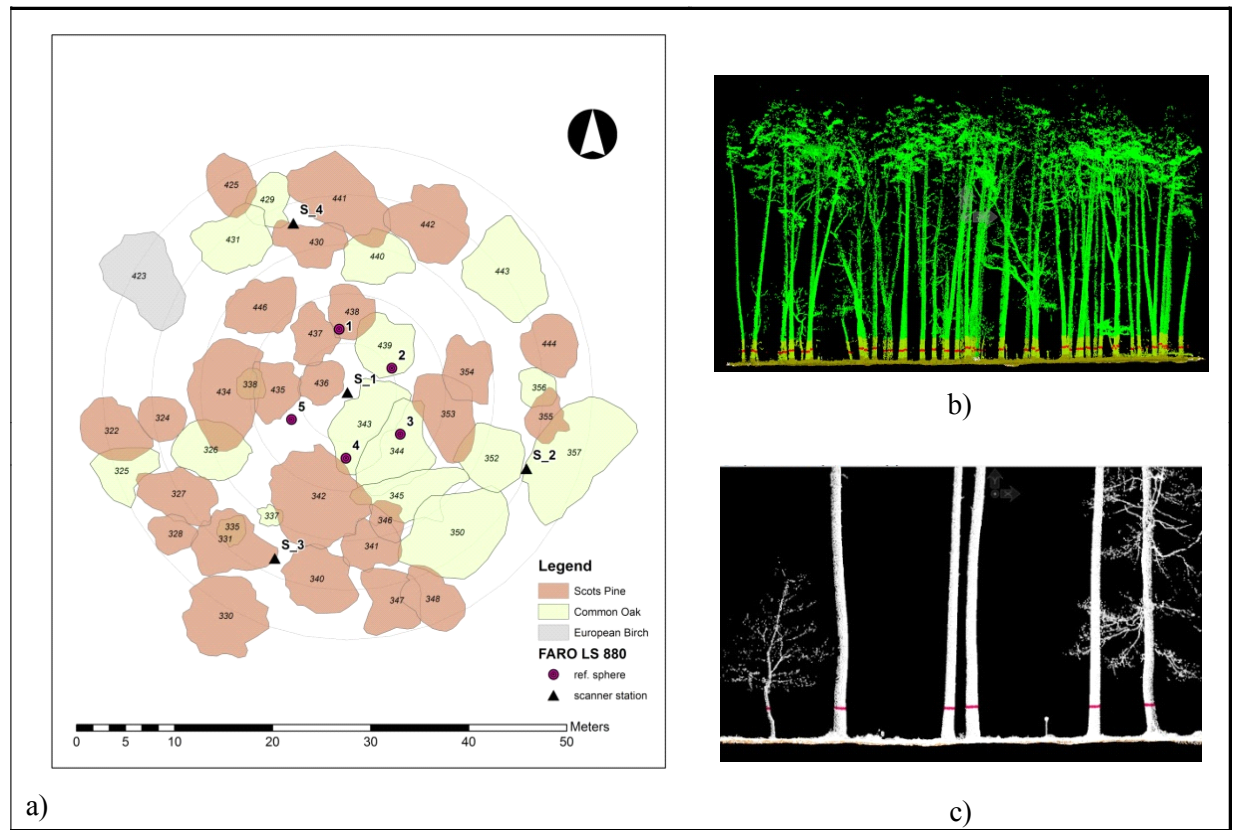

Figure 4. Map of FARO scanner stations, spheres and tree crowns on the experimental $25 \mathrm{~m}$ radius inventory plot (a), the N-S Profile trough TLS classified point cloud data (b) and enlarged part (magenta slices: DBH I.28-1.32 m above DTM; (c)). 
in a defined coordinate system, thus it is easier to make transformation from LSRS $(0,0,0)$ into ALS (UTM34N). In the first step the translation of the height system of the TLS point cloud was made (TerraScan, Terrasolid). This requires the classification of the ground (TScan/Classify/Routine/Ground) in the TLS data set. The DTM quality is crucial for further analyses e.g. automatic classification of points of the high vegetation above the ground or to generate the slices of the trunk $(\mathrm{DBH})$ or define the height of the trees $\left(\mathrm{Z}_{\max }\right.$; 95 percentile). In the study the active model method triangulated irregular network (TIN) was applied (AXELSSON, 2000; Terrasolid). The $Z$ value on the ground in the closest point from S_1 (FARO Scene) indicated that the mirror of the scanner was on the height +1.66 over the local DTM. The TLS point cloud was raise on the axis $Z$ to obtain the value $Z=0.0$ $\mathrm{m}$ (DTM relative level). As the ultimate value $\mathrm{Z}$ the heights of points of ground ALS were accepted in the same localizations covered by TLS and ALS (measurement on the ground in the gaps). Due to different grass vegetation (Sept. and Nov. 2006) on TR2, this method turned out to have an error of about 0.32 $\mathrm{m}$. It was replaced by a static measurement of scanner stand (S_1) made by dGPS and total station (UTM34N; X=455965.05, $Y=5543361.17, Z=196.67$ MSL; Figure 4).

The TLS point cloud was transformed from the LSRS using macro: Transformation/ Linear (TerraScan) into the real UTM 34N projection. Then it was necessary to rotate the TLS data, due to a small angular difference (connected with indicating the direction of the scan beginning, i.e. North with the use of compass). From stand S_1, the azimuth angles to the closest 4 tree trunks $(436,437,438$ and 439) were determined and compared to the readings of the planar view (FARO Scene ver. 4.0). The values of angular difference were calculated into radians and the TLS point clod was rotate by macro Transformation/3D translate \& rotate (TerraScan).

\section{Measurement DBH in the Point Cloud TLS}

In the planar view (FARO Scene) the measurements of tree diameter at breast height $(\mathrm{DBH})$ were carried out with a reference manual method (later on called PIXEL) and semi-automatic methods (so-called PIPE). The first method meant indicating edges pixels representing the tree trunk at the height 1.3 over the local ground. The second method meant indicating the vertical and horizontal axes of the trunk running through the point of the stem height of $1.3 \mathrm{~m}$ above the ground. Another method applied was fully automatic and meant the application of the author's algorithm "Slice" to define the basal area of $4 \mathrm{~cm}$-thick slice of the TLS point cloud cut from the tree trunk (WEZYK et al., 2007). The TLS data was subdued to automatic classification with the application of macro, which allowed create the class DBH_1.3 $(1.28 \div 1.32 \mathrm{~m}$ above DTM; Figure $4 \mathrm{c}$; TerraScan).

\section{Results}

\section{The dGPS and Tachymetry Survey}

Static observations of dGPS were calculated and equalized in the software Leica Geo Office (ver. 7.0) in the reference to the closest reference stations (KRAW and PROSZ) of network ASG-EUPOS. The series of static dGPS measurements referred to precise marking the position and direction of the initial point of transverse GPS_10 
and reference GPS_11. The measurement observations of these points lasted $3 \mathrm{~h} 45^{\prime} 30$ " and $3 \mathrm{~h} 13^{\prime} 05^{\prime}$ "respectively on the Ionospherefree frequency (phase observation L3) with the application of measurement solution "Phase: all fix" (horizontal mask: 15"). The error of the dGPS static measurement did not exceed the value $0.01 \mathrm{~m}$. The applied corrections (Lat./ Long./Hgt.) were only: $+0.0002,-0.0014$ and $-0.0012 \mathrm{~m}$. The traverse made using the total station had acceptable angle-linear deviations on the level of $\pm 0.03 \mathrm{~m} \div 0.05 \mathrm{~m}$ (XYZ). Defined by total station azimuths to 4 trees allowed the rotation of the point cloud TLS by $5.5^{\circ}$ (0.09599 radians). This way a TLS point cloud was prepared to direct integration, artificially adding to each TLS point attribute a „1"(ALS data received = “2”) by the automatic order ,Flightline numbering/
Assign constant" (TerraScan), which allows the visualization of points in distinct colours and the control of the integration process.

\section{The Statistics of Point Cloud TLS and ALS}

The TLS and ALS point clouds (Figure 5) were subdued to automatic macros, the result of which is presented below (Table 1). Inside the inventory circle plot of the radius of $25 \mathrm{~m}$ (area ca. $2000 \mathrm{~m}^{2}$ and volume $~ 60.000$ $\mathrm{m}^{3}$ ) about 2172 times more TLS beams were recorded than ALS echo's. Counting these values into density (volume) units indicates that TLS points are about $420 \mathrm{pts} / \mathrm{m}^{3}$ and ALS points are only $0.2 \mathrm{pts} / \mathrm{m}^{3}$.

Based on the selected (from the TLS point cloud) sets of single trees

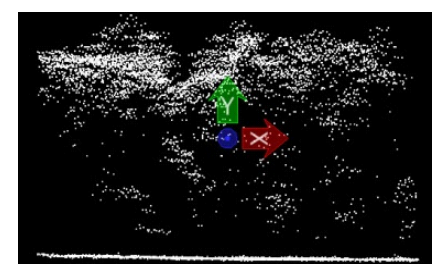

a)

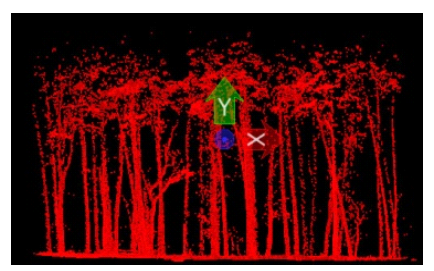

b)

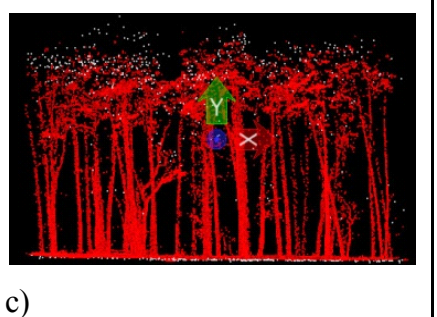

c)

Figure 5. Profiles of the:ALS (a), TLS (b) and integrated A\&T Laser Scanning (c) point cloud.

Table I. Base statistic of the TLS,ALS and integrated (A\&TLS) point clouds

\begin{tabular}{lccccccc}
\hline Class & $\begin{array}{c}\text { TLS } \\
\text { (pts.) }\end{array}$ & $\begin{array}{c}\text { TLS } \\
\text { class (\%) }\end{array}$ & $\begin{array}{c}\text { ALS } \\
\text { (pts.) }\end{array}$ & $\begin{array}{c}\text { ALS } \\
\text { class (\%) }\end{array}$ & $\begin{array}{c}\text { all A\&T } \\
\text { LS (pts.) }\end{array}$ & $\begin{array}{c}\text { \% TLS of } \\
\text { all pts. }\end{array}$ & $\begin{array}{c}\text { \% ALS } \\
\text { of all pts }\end{array}$ \\
\hline $\begin{array}{l}\text { ground } \\
(0.00 \mathrm{~m})\end{array}$ & 93650.00 & 0.38 & 1808 & 15.84 & 95458.00 & 98.11 & 1.89 \\
$\begin{array}{l}\text { low veg. } \\
(0.0 \div 0.5 \mathrm{~m})\end{array}$ & 19130708.00 & 77.18 & 2222 & 19.47 & 19132930.00 & 99.99 & 0.01 \\
$\begin{array}{l}\text { medium veg. } \\
(+0.5 \div 2.5 \mathrm{~m})\end{array}$ & 867580.00 & 3.50 & 3 & 0.03 & 867583.00 & 100.00 & 0.00 \\
$\begin{array}{l}\text { high veg. } \\
(>2.50 \mathrm{~m})\end{array}$ & 4596483.00 & 18.54 & 7378 & 64.66 & 4603861.00 & 99.84 & 0.16 \\
$\begin{array}{l}\text { DBH_1.3 } \\
(+1.28 \div 1.32)\end{array}$ & 98928.00 & 0.40 & - & - & 98928.00 & 100.00 & 0.00 \\
SUM & 24787349.00 & & 11411 & & 24798760.00 & - & - \\
\hline
\end{tabular}


(inside the outlines of crowns) without the representation of ground class, it was calculated that on the trunks of Scots pine and common oak there were $77.5 \%$ and $81.4 \%$ of the total points, respectively. The crowns were represented by $21.1 \%$ and $9.4 \%$ points TLS, respectively (oaks were scanned in November; the "leaf-off" period) and thicker branches by $1.4 \%$ and $7.6 \%$.

The below presented histogram (FUSION-GRIDMETRIS;McGAUGHEY, 2012) of the vertical distribution of the integrated A\&TLS point cloud of a single Scots pine $(\mathrm{ID}=342 ; \mathrm{DBH}=69.2$ $\mathrm{cm}$; HALS $=30.65 \mathrm{~m}$ ) with very dense crown, demonstrates that TLS and ALS technologies are complementary. In the top part of the pine crown (Figure 6a), it can be noticed many ALS laser hits, while in the lower part of the crown the domination of TLS points can be observed (Figure 6b).

\section{Measurements of Selected Taxation Teatures in the TLS Point Cloud}

The mean $\mathrm{DBH}$ for the analyzed trees on a typical circle plot radius $(\mathrm{r}=12.62$ $\mathrm{m})$ was $44.46 \mathrm{~cm}$ (Scots pine) and $38.34 \mathrm{~cm}$ (common oak). The reference values of mean tree trunk perimeter were for these species $134.88 \mathrm{~cm}$ and $115.49 \mathrm{~cm}$ respectively. The perimeter measured with a tape increased $\mathrm{DBH}$ of the Scots pine by about $+0.69 \mathrm{~cm}$ (reference: mean of 5 different measurements of DBH_ $1 \div 5)$ and by $+0.79 \mathrm{~cm}$ for the common oak. The DBH carried out in FARO Scene were different from the reference values of about $0.03 \%$ (PIXEL) and 2.30\% (PIPE; Table 2). The PIXEL method increased the

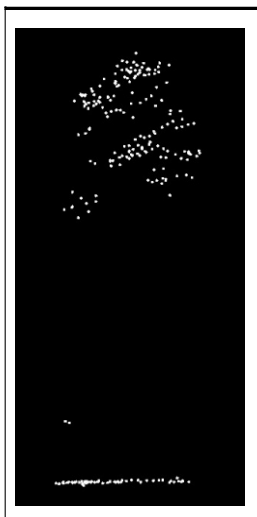

a)

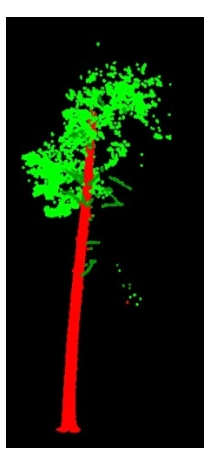

b)

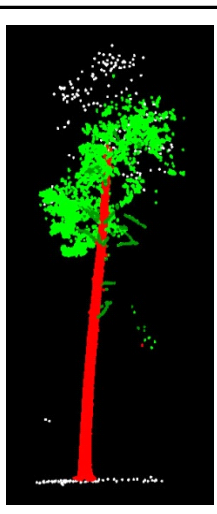

c)

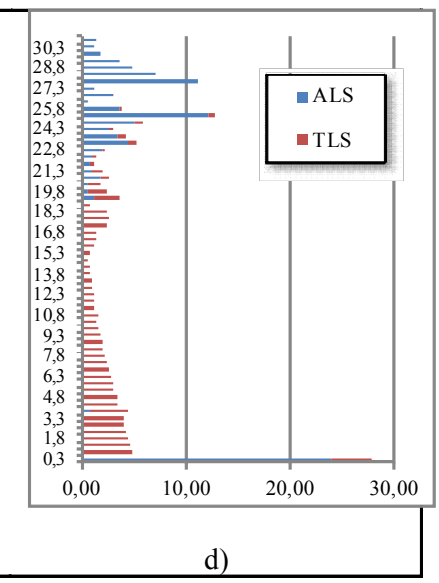

d)

Figure 6. Profiles of the:ALS (Scots pine ID=342; white 445pts.; (a)),TLS with classes: stem (232.247 pts), branches (10.357 pts.), crown (46.106 pts.) (b) and A\&T LS integrated point cloud (c) with the histogram (d).

Table 2. Differences of DBH deriving from the TLS point cloud with different methods

\begin{tabular}{|c|c|c|c|c|c|c|c|c|c|c|}
\hline $\begin{array}{l}\text { Tree } \\
\text { species }\end{array}$ & $\begin{array}{l}\text { PIXEL } \\
\text { DBH } \\
\text { mean } \\
(\%)\end{array}$ & $\begin{array}{l}\text { PIXEL } \\
\text { DBH } \\
\text { mean\% } \\
\text { (mode) }\end{array}$ & $\begin{array}{l}\text { PIPE } \\
\text { mean } \\
\text { DBH } \\
(\%)\end{array}$ & $\begin{array}{l}\text { PIPE } \\
\text { DBH } \\
\text { mean\% } \\
\text { (mode) }\end{array}$ & $\begin{array}{l}\text { "slice" } \\
\text { DBH1 } \\
\text { (cm) }\end{array}$ & $\begin{array}{l}\text { "slice" } \\
\text { DBH1 } \\
\text { (\%) }\end{array}$ & $\begin{array}{l}\text { „slice” } \\
\text { DBH_1 } \\
\% \\
\text { (mode) }\end{array}$ & $\begin{array}{l}\text { „slice” } \\
\text { DBH } \\
\text { mean } \\
(\mathrm{cm})\end{array}$ & $\begin{array}{l}\text { "slice" } \\
\text { DBH } \\
\text { mean } \\
\text { (\%) }\end{array}$ & $\begin{array}{l}\text { „slice” } \\
\text { DBH } \\
\text { mean \% } \\
\text { (mode) }\end{array}$ \\
\hline pin & 1.27 & 2.90 & 200 & 5.61 & & & 4.93 & -1.48 & -2.23 & 3.7 \\
\hline oak & -1.06 & 3.06 & 1.82 & 4.06 & -0.57 & -1.60 & 2.30 & -0.88 & -3.05 & 2.78 \\
\hline all trees & 0.03 & 3.20 & 2.30 & 5.28 & -1.10 & -2.67 & 4.21 & -1.24 & -2.83 & 3.60 \\
\hline
\end{tabular}


DBH values of about $1.27 \%$ for the Scots pine, which could be caused by the bark peeling on the trunk. In case of the common oak the opposite trend was observed, which can indicate the limited resolution of TLS data. In case of the semi-automatic PIPE method, the formed cylinders increased the real $\mathrm{DBH}$ value by almost $2.0 \%$ both for the Scots pine as well as common oak. Such situation is caused by adjusting the cylinder into the point cloud of an irregular part of the tree trunk (e.g. slightly twisted or with the defects of the wood). Mean absolute values for these differences were significantly higher and equaled $3.20 \%$ for methods PIXEL and 5.28\% for PIPE, respectively.

The applied method of automatic definition of DBH with "Slice” algorithm (WEZYK et al. 2007) based on TLS point class "DBH_1.3" (Figure 4c), in the first step leads to the definition of the area of the convex hull, i.e. "g” (basal area), which is sought by the foresters to define the wood volume of tree stands. Based on "g", the $\mathrm{DBH}$ or radius can be calculated in reverse method if necessary. It turns out that comparing the value of $\mathrm{DBH}_{-}$Slice with reference measurement DBH_1 (calliper) the error was $-1.10 \mathrm{~cm}$ (Table 2; calliper measurement lowered for all the trees of about 2.67\%; for the Scots pine 2.77\%, common oak 1.6\%;). The comparison of methods with the use of algorithm "Slice" to 5 reference measurements with the calliper (DBH_mean) gave very similar results, slightly higher for the common oak (lowering $0.88 \mathrm{~cm} ;-3.05 \%$ ). Analyzing the mean absolute values of the differences showed that for all the species it was 3.60\% (Scots pine 3.7\%; common oak 2.78\%) in case of the comparison with the mean of 5 measurements with the calliper.

Based on the $\mathrm{DBH}$ point class (Figure $7 b, c)$ the "Slice" algorithm, returned the precise coordinates of the centroid of the created convex hull and the map of tree

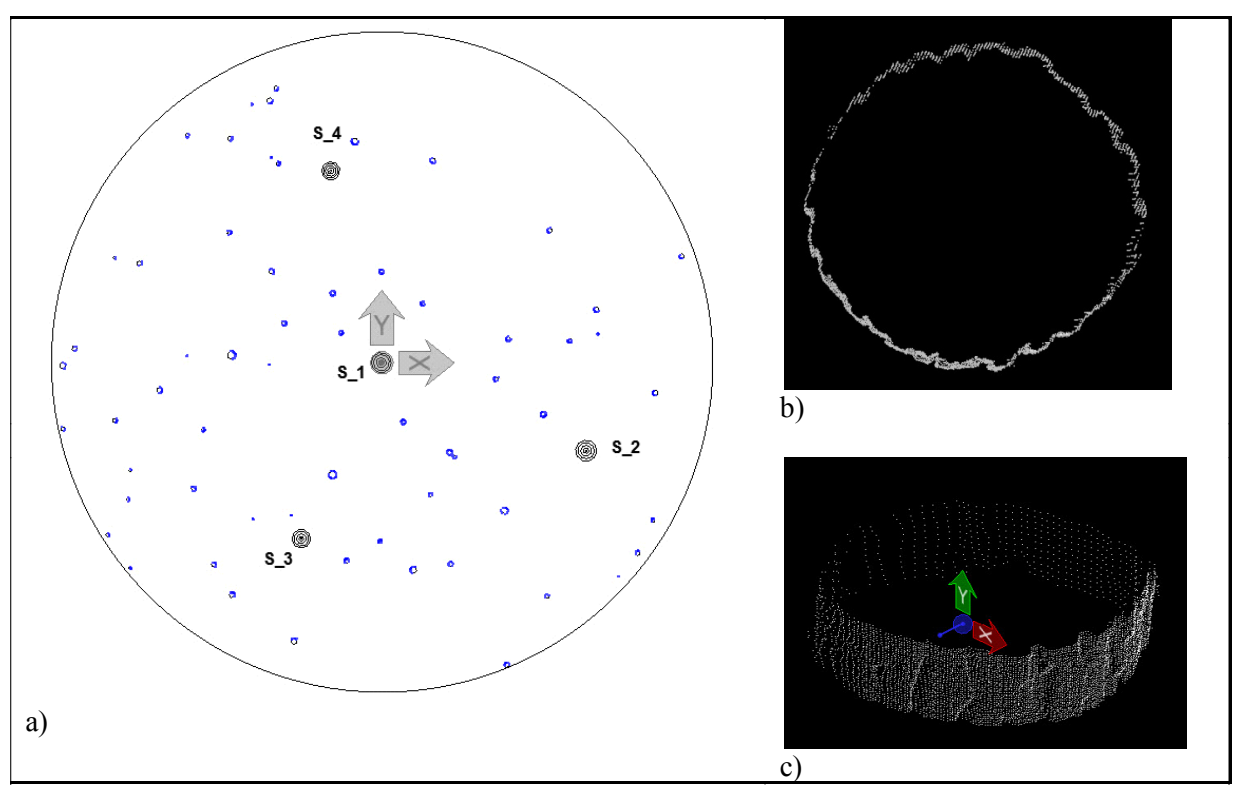

Figure 7. Map of tree stem positions (slices) at the TR2_TLS area (S_I $\div 4$ scanner positions) (a), Slice trough pine ID=342 at the height I.28-I.32 above DTM (b) and Isometric view of $4 \mathrm{~cm}$ slice $(\mathrm{c})$ 
stem was done (Figure 7a). The CAD/GIS analyses allows making the azimuth table and distance table to every tree of $\mathrm{S}_{-} 1$, even if it is concealed by another trunk. In the class "ground" and "low vegetation" the areas (diameter approx. $1.4 \mathrm{~m}$ ) without the TLS points were detected as the scanner stands (S_2 was: $19.7 \mathrm{~m}$ and $112^{\circ}$ form S_1 position, and subsequent ones: S_3: $17.5 \mathrm{~m}$ and $201.5^{\circ}$ and S_4: $17.97 \mathrm{~m}$ and $341.5^{\circ}$ ). This allows to make the map of the scanner positions and spheres (Figure $7 \mathrm{a}$ ).

\section{Height of the Trees And the Characteristics of the Crowns (TLS \& ALS)}

The mean height of the common oak(I storey), derived on the TLS point cloud with the application GNOM (RATAJCZAK, 2010) was $23.70 \mathrm{~m}$ (5.99 m - II storey; 5 oaks), Scots pine: $26.15 \mathrm{~m}$ and silver birch $25.48 \mathrm{~m}$. The same point cloud interpreted by the operator in TerraScan gave values: -1.0 $\mathrm{m}$ lower for Scots pine and the respective results for the oak and birch were: $-0.27 \mathrm{~m}$ and $-1.20 \mathrm{~m}$. Automatic analyses carried out on the ALS point cloud showed mean height for the common oak form Ist storey: $23.97 \mathrm{~m}$ (6.08 IInd storey), the Scots pine: $27.10 \mathrm{~m}$ and silver birch: $26.65 \mathrm{~m}$. The mean height differences between ALS and TLS data for all analyzed trees of I storey were approx. $0.63 \mathrm{~m}$, indicating lowering this parameter by TLS technology. The main problem of TLS is in the limitation in the ability of laser beams to reach the tree top parts, limited scanning resolution and seasonal differences in LAI (oak).

Application GNOM in its subsequent modification is now able to define the base of crown (bc), diameter and maximal radius (one of 8 main directions). Based on these values the: length of crown (1c), 2D and 3D surfaces as well as volume $\left(\mathrm{V} / \mathrm{m}^{3}\right)$ of the tree crown can be calculated (Table 3 ).

Using the Cloudmetrix (FUSION; McGAUGHEY 2012; Table 4) it was possible to derive the characteristics of ALS and TLS point clouds, as well as integration of both data sources. The Cloudmetrix worked on the prepared point sets of single trees (files *.LAS) cut with the TLS outlines of tree crowns (function Polyclipdata; FUSION). On average the single Scots pine crown contained 189 impulses of ALS beams.

Table 3. The characteristics of the tree crowns of the I storey of the tree stand on TR2_TLS $(r=25 \mathrm{~m})$

\begin{tabular}{ccccccccc}
\hline $\begin{array}{c}\text { Spec./n } \\
\text { pcs.] }\end{array}$ & Statistics & $\mathbf{h}_{\mathbf{t}}[\mathbf{m}]$ & $\mathbf{b}_{\mathbf{c}}[\mathbf{m}]$ & $\mathbf{1}_{\mathbf{c}}[\mathbf{m}]$ & $\mathbf{r}_{\mathbf{c}}[\mathbf{m}]$ & $\begin{array}{c}\text { area 2D } \\
{\left[\mathbf{m}^{2}\right]}\end{array}$ & $\begin{array}{c}\text { area 3D** } \\
{\left[\mathbf{m}^{2}\right]}\end{array}$ & $\begin{array}{c}\mathbf{V c}^{* * *} \\
{\left[\mathbf{m}^{3}\right]}\end{array}$ \\
\hline Pine & mean & 27.10 & 17.41 & 9.08 & 3.14 & 32.8 & 80.4 & 84.0 \\
23 & std. dev. & 1.69 & 2.42 & 2.74 & 0.76 & 16.23 & 43.04 & 69.55 \\
Oak* & mean & 23.97 & 13.24 & 11.40 & 3.77 & 46.15 & 159.4 & 288.7 \\
16 & std. dev. & 1.86 & 5.12 & 5.64 & 0.72 & 18.45 & 62.76 & 143.90 \\
$\begin{array}{c}\text { Birch } \\
1\end{array}$ & mean & 27.25 & 20.25 & 7.00 & 4.1 & 53.80 & 105.7 & 111.3 \\
\hline
\end{tabular}

Note: * only I storey, ht [m] - height of tree top; bc [m]- base of crown; lc [m]- length of crown; rc [m] - radius of crown; area 3D ** - cone; $V \mathrm{c}$ - volume of crown [m3;] *** paraboloid. 
Table 4. The example of the values of indexes (metrix) obtained by the function Cloudmetrix (FUSION) on ALS datasets for single trees

\begin{tabular}{lllllllllll}
\hline Tree_id & $\mathbf{3 4 2}$ & $\mathbf{3 2 6}$ & $\mathbf{4 2 5}$ & $\mathbf{3 2 4}$ & $\mathbf{4 2 9}$ & $\mathbf{4 2 3}$ & $\mathbf{4 3 4}$ & $\mathbf{3 5 4}$ & $\mathbf{3 4 1}$ & $\mathbf{3 4 8}$ \\
\hline ALS points [pts] & 445 & 189 & 92 & 47 & 52 & 209 & 266 & 105 & 115 & 126 \\
Elevation parameters: & & & & & & & & & & \\
min. [m] & 0.0 & 0.0 & 0.2 & 0.0 & 0.2 & 0.1 & 0.0 & 0.0 & 0.0 & 0.2 \\
max. [m] & 30.6 & 30.0 & 29.9 & 29.8 & 29.5 & 28.6 & 28.6 & 28.5 & 28.3 & 28.2 \\
mean [m] & 22.8 & 20.3 & 20.8 & 21.7 & 19.5 & 14.4 & 23.6 & 21.0 & 23.2 & 24.0 \\
median [m] & 25.6 & 23.0 & 25.9 & 27.7 & 24.4 & 21.2 & 27.3 & 25.0 & 23.5 & 24.7 \\
mode [m] & 27.7 & 0.0 & 0.2 & 27.4 & 23.9 & 0.1 & 27.2 & 25.8 & 22.9 & 24.6 \\
std. dev. [m] & 9.2 & 8.3 & 10.6 & 11.5 & 9.4 & 12.6 & 8.6 & 9.2 & 4.2 & 3.9 \\
variance & 84.6 & 69.6 & 113.4 & 132.3 & 89.0 & 158.0 & 74.7 & 85.1 & 17.7 & 15.0 \\
Percentile 5 & 0.0 & 0.1 & 0.3 & 0.0 & 5.6 & 0.2 & 0.1 & 0.0 & 19.1 & 19.8 \\
Percentile 10 & 0.1 & 0.2 & 0.5 & 0.0 & 6.1 & 0.2 & 0.1 & 0.1 & 20.6 & 21.0 \\
Percentile 90 & 29.1 & 27.2 & 29.6 & 29.4 & 28.2 & 27.7 & 28.1 & 27.1 & 25.2 & 27.7 \\
Percentile 95 & 29.6 & 28.6 & 29.8 & 29.6 & 28.7 & 27.9 & 28.2 & 27.9 & 25.7 & 28.0 \\
\hline
\end{tabular}

\section{The Density OfThe Tree Stand}

The reference value of canopy closure has based on vectorization of the TLS point cloud (range of the crown) and was $76.9 \%$. Should they, however bear in mind that TLS was carried out during the leaf-off period, thus inaccuracies in the crown shape were possible. The nDSM (GSD $0.5 \mathrm{~m}$; smoothed surface, median filter $3 \times 3$; FUSION) was generated automatically based on the ALS point cloud normalized using precise DTM. The model was exported as ASCII GRID and in the ArcGIS10 Esri it was reclassified into two ranges separated by the height of the crown base (Figure 8). The crown base was automatically computed (GNOM): for the common oak as $13.24 \mathrm{~m}$ (only trees of I storey) and Scots pine: $17.41 \mathrm{~m}$. The value of canopy closure of the TR2_TLS plot obtained by Spatial Analyst (Esri) for the base of the crown of $13.0 \mathrm{~m}$ was: $71.1 \%$ (gaps made 28.9\%). This relatively small error of $5.8 \%$ can be totally neglected comparing to the traditional methods of crown closure estimation.

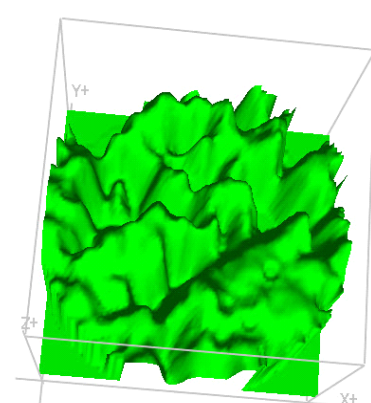

a)

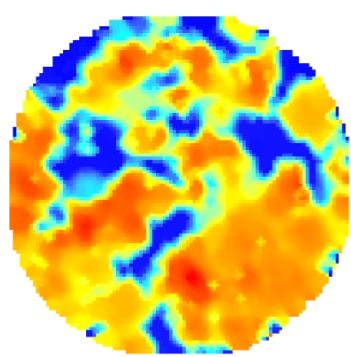

b)

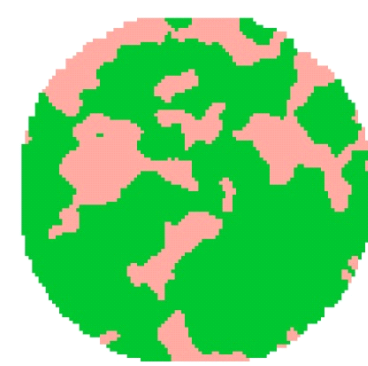

c)

Figure 8. Isometric view of $n D S M$ ofTR2_ALS $(r=25 \mathrm{~m})$ inventory plot (a), nDSM ofTR2_ALS inventory plot (b) and reclassified nDSM, green: crowns $\mathrm{h}>13$ m; pink: gaps $<13 \mathrm{~m}<0$ (c). 


\section{Discussion}

A large part of the studies in the recent years focused on the increase of the speed and accuracy of automatic algorithms to apply the crown of trees on DSM or nDSM models (WEZYK et al., 2010; POPESCU; WYNNE, 2004) or automatic measurement of tree trunks. Bienert et al. (2007) with the TreeMetrics company made the program of AutoStem, allowing the automatic measurement of tree parameters (number of trees, area of cross-section at any height, the situation of the tree in the area and the height of the top) in the TLS point cloud. There were also attempts, described by Maas et al. (2008) of detection and measurement of trees with a method based on so called voxels (GORTE; PFEIFER, 2004). However, it turned out to be of little efficiency, because at best it was possible to detect only $52 \%$ trees, and the measurement of the trunk diameter was characterized by the standard deviation of $3.5 \mathrm{~cm}$. The integration of TLS and ALS clouds (A\&T LS; Airoborne\&Tererstrial Laser Scanning) based on surveying measurements is nowadays possible due to the development of GNSS technologies (the reception of satellites GPS-NAVSTAR and GLONASS) as well as the network of reference stations (e.g. ASG-EUPOS). The precision of the transformation of TLS point clouds from the local system $(0,0,0)$ to the system of coordinates exceeds many times (about 4-6x) the precision of ALS point cloud georeferencing, because the forest area are usually lacking planar surfaces (i.e.: buildings, infrastructure) where the adjustment in to the defined $\mathrm{XYZ}$ coordinate system is made. The integration of A\&T LS data provides the increase of the accuracy of the measurement of the: tree top heights, density, crown base and length or storey structure and enables the transposition of the results on large forest areas, for which statistical models are constructed in order to estimate the wood biomass (WEZYK; SROGA, 2010). Looking at the research trends and the publications of other authors, the papers on the LiDAR application (like development of GNOM and other methods; WEZYK et al., 2009, 2010a) of in forestry carried out since 2006 in the Laboratory of Geomatics (Faculty of Forestry, Agricultural University in Krakow, Poland) looks very promising. The integration of TLS and ALS supported by the Photogrammetry (i.e. CIR) or VHRS images can offer much more to forest inventory techniques then the separated techniques.

\section{References}

ANDERSEN, H. E.; REUTEBUCH, S. E.; McGAUGHEY, R. J. A rigorous assessment of tree height measurements obtained using airborne lidar and conventional field methods. Canadian Journal of Remote Sensing, v.32, n.5, p. 355-366, 2006.

AXELSSON, P. DEM generation from laser scanner data using adaptive TIN models. ISPRS Journal of Photogrammetry \& Remote Sensing, v.54, p.138-147, 2000.

BIENERT, A.; SCHELLER, S.; KEANE, E.; MOHAN, F.; NUGENT, C. Tree detection and diameter estimations by analysis of forest terrestrial laser scanner point clouds. International Archives of Photogrammetry. Remote Sensing and Spatial Information Sciences, v.XXXVI, Part 3/W52, p.50-55, 2007. 
CHASMER, L.; HOPKINSON, C.; TREITZ, P. Investigating laser pulse penetration through a conifer canopy by integrating airborne and terrestrial lidar. Canadian Journal of Remote Sensing, v.32, n.2, p.116-125, 2006.

DANSON,F.M.;HETHERINGTON,D.;MORSDORF,F.; KOETZ,B.;ALLGOEWER, B. Three-dimensional forest canopy structure from terrestrial laser scanning. In: KOUKAL T.; SCHNEIDER W. (Eds.): 3-D Remote Sensing in Forestry, Vienna. EARSeL SIG Forestry SIG Forestry. ISPRS WG VIII/11, p.50- 54, 2006.

DONEUS, M.; BRIESE, C.; STUDNICKA, N. Analysis of Full-Waveform ALS Data by Simultaneously Acquired TLS Data: Towards an Advanced DTM Generation in Wooded Areas. In: WAGNER, W.; SZÉKELY, B. 100 Years ISPRS, Advancing Remote Sensing Science. ISPRS Technical Commission VII Symposium, Vienna, Austria, July 5- 7, 2010. IAPRS. Vol. XXXVIII, Part 7B, p.193-198. 2010.

GORTE, B.; PFEIFER, N. Structuring laser-scanned trees using 3D mathematical morphology. International Archives of Photogrammetry and Remote Sensing, v.35, (B5), p.929-933. 2004.

HANSEN, W.; GROSS H.; THOENNESSEN U. Line-based registration of terrestrial and airborne LiDAR data. The International Archives of the Photogrammetry, Remote Sensing and Spatial Information Sciences, v.XXXVII. Beijing, Part B3a.p.161-166. 2008.

HOLLAUS, M.; WAGNER W.; MAIER B.; SCHADAUER K. Airborne laser scanning of forest stem volume in a mountainous environment. Sensors, v.7, n.8, p. 1559-1577, 2007.

HOPKINSON, C.; CHASMER, L.; YOUNG-POW, C.; TREITZ, P.. Assessing forest metrics with a ground-based scanning lidar. Canadian Journal of Forest Research, v.34, n.3, p.573-583, 2004

HYYPPÄ, J.; HYYPPÄ, H.; LITKEY, P.; YU, X.; HAGGRÉN, H.; RÖNNHOLM, P.; PYYSALO, U.; PITKANEN, J.; MALTAMO, M. Algorithms and methods of airborne laser-scanning for forest measurements. In: THIES, M.; KOCH, B.; SPIECKER, H.; WEINACKER, H. (Eds.). Laser-Scanners for Forest and Landscape Assessment: Proceedings of the ISPRS Working Group VIII/2. Freiburg, Germany. International Archives of Photogrammetry, Remote Sensing, and the Spatial Information Sciences.XXXVI-8/W2, p.82-89. 2004.

KAGER, H. Discrepancies between overlapping laser scanner strips - simultaneous fitting of aerial laser scanner strips. International Archives of Photogrammetry, Remote Sensing and Spatial Information Science. Istanbul, Turkey, v.35, Part B/1, p.555-560. 2004.

KOK, R.; WEZYK, P. Principles of full autonomy in image interpretation. The basic architectural design for a sequential process with image objects. In: BLASCHKE, T.; LANG. S.; HAY, G.J. (Eds.). Object-based image analysis. Series: Lecture Notes in Geoinformation and Cartography. Springer, Berlin Heidelberg, p. 697-710. 2008. 
MAAS, H-G.; BIENERT, A.; SCHELLER, S.; KEANE, E. Automatic forest inventory parameter determination from terrestrial laser scanner data. International Journal of Remote Sensing, v.29, n.5, p.1579-1593. 2008.

McGAUGHEY, R.J. FUSION/LDV: Software for LIDAR data analysis and visualization. Software Manual. FUSION - version. 3.10. USDA Forest Service. Pacific Northwest Research Station. 2012.

PERRY, J.; CHILDS, J. Timing on the fly. Synchronization for direct georeferencing on small UAV's. InsideGNSS. November/December, p.34-40. 2009.

POPESCU, S.C.; WYNNE, R. H.; NELSON, R.F. Measuring individual tree crown diameter with LiDAR and assessing its influence on estimating forest volume and biomass. Canadian Journal of Remote Sensing, v.29, n.5, p.564-577, 2003.

POPESCU, S. C.; WYNNE, R. H. Seeing the trees in the Forest: Using lidar and multispectral data fusion with local filtering and variable window size for estimating tree height. Photogrammetric Engineering \& Remote Sensing, v.70, n.5, p.589-604, 2004.

RATAJCZAK, M. Automatic extraction and modelling of the selected tree over ground part of Scots pine (Pinus silvestris L.) based on the TLS point cloud. Master Thesis. Agricultural University in Krakow,2010.

SOCHA, J.; WEZYK, P. Allometric equations for estimating the foliage biomass of Scots pine. European Journal of Forest Research, v.126, n.2, p. 263-270, 2007.

WEIDENBACH, M.; DE KOK, R.;WEZYK, P.; SZOMBARA, S. Developing strategies for large scale forest inventories combining LiDAR data, satellite imagery and regional yield models. In: $\mathbf{8}^{\text {th }}$ international conference on LiDAR applications in forest assessment and inventory. SiliviLaser 2008. Sept. 17-19.2008 - Edinburgh, UK, p.635. 2008

WEZYK, P. The LiDAR point cloud data-based forest canopy modelling. Archive of Photogrammetry, Cartography and Remote Sensing, v.18b, p.685-695, 2008.

WEZYK, P.; SIECZKA, A. Describing the canopy closure of forest stands using the method based on the airborne laser scanning at the example of Chojna forest district. Geoinformatica Polonica, v.10, p.75-84, 2010.

WEZYK, P.; SROGA, R. Terrestrial laser scanning in the inventory of Scots pine stand volume. Annals of Geomatics, v.8, n.7(43), p.63-73, 2010.

WEZYK, P.; TOMPALSKI, P. Determining stem density parameter in pine stands based on terrestrial laser scanning point cloud analysis. Annals of Geomatics, v.8, n.7(43), p.83-90, 2010. 
WEZYK, P.; KOZIOŁ, K.; GLISTA, M.; PIERZCHALSKI, M. Terrestrial laser scanning versus traditional forest inventory. First results From the Polish forests. IAPRS Volume XXXVI, Part 3/W52.ISPRS Workshop on Laser Scanning 2007 and SilviLaser 2007, Espoo, September 12-14 2007, Finland, p. 424-429, 2007.

WEZYK, P.; SROGA R.; SZWED, P.; SZOSTAK, M.; TOMPALSKI, P.; KOZIOŁ, K. The application of terrestrial laser scanning for determining the selected trees and forest stand parameters. Archive of Photogrammetry, Cartography and Remote Sensing, v.19, p. 447-457, 2009.

WEZYK, P.; TOMPALSKI P.; SZOSTAK M.; GLISTA, M.; PIERZCHALSKI, M. Describing the selected canopy layer parameters of the Scots pine stands using ALS data. In: $8^{\text {th }}$ International conference on LiDAR applications in forest assessment and inventory. SiliviLaser, September 17-19 2008, Edinburgh, UK, p. 636-645, 2008.

WEZYK,P.;TOMPALSKI, P.; DE KOK, R.; SZOSTAK, M.; KUKAWSKI, M.Method of the tree number estimation in the pine stand using ALS data and true orthoimages. Sylwan, v.154, n.11, p.773-782, 2010a.

WEZYK, P.; SZOSTAK, M.; TOMPALSKI, P. Development of a method for automated stand height determination based on airborne laser scanning data and its evaluation in Milicz forest disctrict. Annals of Geomatics, v.8, n.7(43), p.73-83, 2010b.

WEZYK, P.; RATAJCZAK, M.; TOMPALSKI, P. Automatic extraction of selected tree taxation parameter of Scots pine based on the TLS point cloud. Posters proceedings of the $5^{\text {th }}$ Conference, GIS in the Polish State Forest National Holding. Rogow 14-15 September, 2010c. 